\title{
INVESTIGATION OF THE CARBONIC ANHYDRASE CONTENT OF THE CORNEA OF THE RABBIT*
}

\author{
BY \\ J. GLOSTER \\ Medical Research Council, Institute of Ophthalmology, London \\ Director of Research: Sir Stewart Duke-Elder
}

THE presence of carbonic anhydrase in ocular tissues has been studied intermittently for more than 10 years, but this matter gained fresh interest after Becker (1954) reported that a reduction of intra-ocular pressure could be obtained in man by the systemic administration of 2-acetylamino-1, 3, 4-thiadiazole-5-sulphonamide (Diamox), a substance which is known to be a powerful inhibitor of carbonic anhydrase.

Bakker $(1939,1941)$ showed that the crystalline lenses of various mammals contained relatively large amounts of this enzyme, and its presence, in lower concentrations, has been demonstrated in the ciliary body and iris of rabbits (Wistrand, 1951; Gloster and Perkins, 1955). However, little attention appears to have been paid to the carbonic anhydrase content of the cornea, apart from a statement by Bakker (1941) that very small quantities of the enzyme are present in this tissue in dogs.

The effect of Diamox, injected intravenously, on the $p \mathrm{H}$ and the concenirations of carbon dioxide and bicarbonate in the aqueous humour of rabbits has been studied recently (Lee, 1955; Langham and Lee, 1955), and, since the cornea, in common with the lens, ciliary body, and iris, comes into direct contact with the aqueous humour, an investigation of the carbonic anhydrase content of the cornea seemed likely to prove of some interest.

\section{Methods}

(1) Preparation of Extracts of Whole Corneae.-The corneae were excised from rabbits less than half an hour after death, care being taken to cut sufficiently far from the limbus to ensure that only avascular tissue was obtained. The corneae were washed rapidly in physiological saline, excess moisture was removed, and the tissues were then weighed.

Corneal extracts " A" and "B" were prepared by cutting the excised corneae into small fragments with scissors and then homogenizing with glass-distilled water in a Blendor (M.S.E.) homogenizer for 30 minutes. The homogenate was then centrifuged and the supernatant liquid stored in a refrigerator until the carbonic anhydrase determinations were carried out.

Corneal extracts " C", " $D$ " and " $E$ " were prepared as follows:

The excised corneae were packed together and were frozen to the block of a freezingmicrotome, small quantities of glass-distilled water being added from time to time. The whole mass of frozen corneae and ice was then cut into $25 \mu$ sections, glass-distilled water was added to a known volume, and the extract was stored overnight at $0^{\circ} \mathrm{C}$. After centrifuging, the supernatant was used for the carbonic anhydrase estimations.

*Received for publication August 12, 1955. 
" Heated" extracts were prepared by keeping some of the extract at $80^{\circ} \mathrm{C}$. in a water-bath for 60 minutes.

(2) Preparation of Extracts of Corneal Epithelium and Endothelium.-The epithelium and endothelium of corneae excised from rabbits, less than half an hour after death, were scraped off separately on to glass cover-slips which were placed in stoppered weighing-bottles. After weighing, the tissues were ground up with a known volume of glass-distilled water in a glass tissue-grinder. The extracts were centrifuged and the supernatant kept at $0^{\circ} \mathrm{C}$. until required for the determination of their carbonic anhydrase activity.

(3) Determination of the Carbonic Anhydrase Content of Extracts.-Carbonic anhydrase activity was determined by a modification of the method of Krebs and Roughton (1948) at $25^{\circ} \mathrm{C}$., using Warburg manometers.

TABLE I

CARBONIC ANHYDRASE DETERMINATIONS ON EXTRACTS FROM CORNEAL TISSUES OF RABBITS

\begin{tabular}{|c|c|c|c|c|c|c|c|}
\hline \multirow{3}{*}{$\begin{array}{c}\text { Experi- } \\
\text { ment } \\
\text { No. }\end{array}$} & \multirow{3}{*}{ Extract } & \multicolumn{6}{|c|}{$\mu 1 . \mathrm{CO}_{2}$ Evolved } \\
\hline & & \multicolumn{2}{|c|}{60 sec. after Mixing } & \multicolumn{2}{|c|}{120 sec. after Mixing } & \multicolumn{2}{|c|}{ Final Volume } \\
\hline & & $\begin{array}{l}\text { Mean } \\
\text { S. E. }\end{array}$ & $\left|\begin{array}{c}\text { No. of } \\
\text { determina- } \\
\text { tions }\end{array}\right|$ & $\begin{array}{l}\text { Mean } \\
\text { S. E. }\end{array}$ & $\underset{\text { determina- }}{\text { Nons }}$ & $\begin{array}{l}\text { Mean } \\
\text { S. E. }\end{array}$ & $\begin{array}{c}\text { No. of } \\
\text { determina- } \\
\text { tions }\end{array}$ \\
\hline 1 & $\begin{array}{l}\text { Uncatalysed } \\
\text { Corneal A } \\
\text { Heated A }\end{array}$ & $\begin{array}{r}94 \div 6 \cdot 8 \\
103 \div 2 \cdot 7 \\
96 \div 3 \cdot 8\end{array}$ & $\begin{array}{l}5 \\
5 \\
5\end{array}$ & $\begin{array}{l}18612 \cdot 5 \\
203 \quad 4 \cdot 2 \\
193 \quad 5 \cdot 3\end{array}$ & $\begin{array}{l}5 \\
5 \\
5\end{array}$ & $\begin{array}{l}572 \div 1 \cdot 7 \\
573 \div 4 \cdot 6 \\
563 \div 7 \cdot 6\end{array}$ & $\begin{array}{l}5 \\
5 \\
5\end{array}$ \\
\hline 2 & $\begin{array}{l}\text { Uncatalysed } \\
\text { Corneal B } \\
\text { Heated B }\end{array}$ & $\begin{array}{l}105 \div 3 \cdot 5 \\
103=1 \cdot 8 \\
102=1 \cdot 9\end{array}$ & $\begin{array}{l}5 \\
5 \\
5\end{array}$ & $\begin{array}{ll}212 & 5 \cdot 4 \\
204 & 2 \cdot 7 \\
204 & 2 \cdot 8\end{array}$ & $\begin{array}{l}5 \\
5 \\
5\end{array}$ & $\begin{array}{l}566 \pm 12 \cdot 8 \\
558 \pm 7 \cdot 6 \\
566 \pm 5 \cdot 2\end{array}$ & $\begin{array}{l}5 \\
5 \\
5\end{array}$ \\
\hline 3 & $\begin{array}{l}\text { Uncatalysed } \\
\text { Corneal C } \\
\text { Heated C }\end{array}$ & $\begin{array}{l}121=3 \cdot 2 \\
116: 1 \cdot 4 \\
117=3 \cdot 1\end{array}$ & $\begin{array}{l}5 \\
5 \\
5\end{array}$ & $\begin{array}{l}234=5 \cdot 5 \\
226=3 \cdot 5 \\
227 \pm 5 \cdot 9\end{array}$ & $\begin{array}{l}5 \\
5 \\
5\end{array}$ & $\begin{array}{l}560=6 \cdot 4 \\
570=8 \cdot 7 \\
570=3 \cdot 1\end{array}$ & $\begin{array}{l}5 \\
5 \\
5\end{array}$ \\
\hline 4 & $\begin{array}{l}\text { Uncatalysed } \\
\text { Corneal D } \\
\text { Heated D }\end{array}$ & $\begin{array}{l}117 \pm 6 \cdot 7 \\
125 \pm 4 \cdot 7 \\
121 \pm 2 \cdot 8\end{array}$ & $\begin{array}{l}5 \\
5 \\
5\end{array}$ & $\begin{array}{l}224 \pm 12 \cdot 8 \\
237 \pm 8 \cdot 3 \\
236 \pm 6 \cdot 7\end{array}$ & $\begin{array}{l}5 \\
5 \\
5\end{array}$ & $\begin{array}{l}575 \pm 5 \cdot 6 \\
567 \pm 9 \cdot 8 \\
577 \pm 7 \cdot 4\end{array}$ & $\begin{array}{l}5 \\
5 \\
5\end{array}$ \\
\hline 5 & $\begin{array}{l}\text { Uncatalysed } \\
\text { Corneal E } \\
\text { Heated E }\end{array}$ & $\begin{array}{l}109 \pm 3 \cdot 2 \\
116 \pm 2 \cdot 2 \\
114 \pm 1 \cdot 9\end{array}$ & $\begin{array}{l}5 \\
5 \\
5\end{array}$ & $\begin{array}{l}209 \pm 4 \cdot 6 \\
224 \div 3 \cdot 7 \\
223 \pm 3 \cdot 0\end{array}$ & $\begin{array}{l}5 \\
5 \\
5\end{array}$ & $\begin{array}{l}558 \pm 5 \cdot 4 \\
572 \pm 10 \cdot 5 \\
577 \pm 2 \cdot 5\end{array}$ & $\begin{array}{l}5 \\
5 \\
5\end{array}$ \\
\hline 6 & $\begin{array}{l}\text { Uncatalysed } \\
\text { Epithelial I } \\
\text { Endothelial I }\end{array}$ & $\begin{array}{l}129 \pm 7 \cdot 6 \\
115 \pm 2 \cdot 3 \\
115=1 \cdot 3\end{array}$ & $\begin{array}{l}8 \\
5 \\
5\end{array}$ & $\begin{array}{l}246 \pm 10 \cdot 3 \\
220 \pm 3 \cdot 0 \\
223 \pm 1 \cdot 0\end{array}$ & $\begin{array}{l}8 \\
5 \\
5\end{array}$ & $\begin{array}{l}570 \pm 7 \cdot 3 \\
575 \pm 5 \cdot 5 \\
582 \pm 9 \cdot 2\end{array}$ & $\begin{array}{l}8 \\
5 \\
5\end{array}$ \\
\hline 7 & $\begin{array}{l}\text { Uncatalysed } \\
\text { Epithelial II } \\
\text { Endothelial II }\end{array}$ & $\begin{array}{l}113 \pm 9 \cdot 8 \\
117 \pm 5 \cdot 7 \\
113 \div 4 \cdot 9\end{array}$ & $\begin{array}{l}5 \\
5 \\
6\end{array}$ & $\begin{array}{l}221 \pm 16 \cdot 6 \\
221 \pm 8 \cdot 5 \\
217 \pm 5 \cdot 1\end{array}$ & $\begin{array}{l}5 \\
5 \\
6\end{array}$ & $\begin{array}{l}566 \pm 6 \cdot 4 \\
575 \pm 5 \cdot 1 \\
560 \pm 5 \cdot 7\end{array}$ & $\begin{array}{l}5 \\
5 \\
6\end{array}$ \\
\hline 8 & $\begin{array}{l}\text { Uncatalysed } \\
\text { Epithelial III } \\
\text { Heated Epith- } \\
\text { elial III }\end{array}$ & $\begin{array}{l}118 \div 7 \cdot 0 \\
131 \pm 4 \cdot 4 \\
126 \div 1 \cdot 9\end{array}$ & $\begin{array}{r}12 \\
5 \\
5\end{array}$ & $\begin{array}{l}230 \pm 11 \cdot 7 \\
249 \pm 9 \cdot 2 \\
238 \pm 3 \cdot 7\end{array}$ & $\begin{array}{r}12 \\
5 \\
5\end{array}$ & $\begin{array}{l}586 \pm 4 \cdot 8 \\
606 \pm 12 \cdot 6 \\
600 \pm 5 \cdot 2\end{array}$ & $\begin{array}{r}12 \\
5 \\
5\end{array}$ \\
\hline & $\begin{array}{l}\text { Endothelial III } \\
\text { Heated Endoth- } \\
\text { elial III }\end{array}$ & $\begin{array}{l}117 \pm 5 \cdot 7 \\
120 \div 2 \cdot 8\end{array}$ & $\begin{array}{l}5 \\
5\end{array}$ & $\begin{array}{l}224 \pm 6 \cdot 2 \\
231 \pm 5 \cdot 0\end{array}$ & $\begin{array}{l}5 \\
5\end{array}$ & $\begin{array}{l}586 \pm 6 \cdot 6 \\
581 \pm 4 \cdot 4\end{array}$ & $\begin{array}{l}5 \\
5\end{array}$ \\
\hline
\end{tabular}


$1 \mathrm{ml}$. of $0.1 \mathrm{M}$ sudium bicarbonate solution was placed in the side-arm, and $1 \mathrm{ml}$. of $0.1 \mathrm{M}$ phosphate buffer $(p \mathrm{H} 6.98)$ in the main body of the flask. $0.2 \mathrm{ml}$. of extract was added to the buffer for determining carbonic anhydrase activity. In determining the rate of the uncatalysed reaction, $0 \cdot 2 \mathrm{ml}$. of glass-distilled water was used instead of extract. After equilibration for 10 minutes, the contents of the flask were mixed, and readings were taken at intervals of 60 seconds for 10 minutes, and also at 20 minutes after mixing; a final reading was taken when no further change was observed. At least five determinations were made of the carbonic anhydrase activity of each extract and of the rate of the uncatalysed reaction.

\section{Results}

In the presence of carbonic anhydrase the rate of carbon dioxide evolution is increased in the early stages of the reaction as compared with the uncatalysed reaction. The volumes of carbon dioxide evolved 60 and 120 seconds after the flask contents had been mixed were, therefore, calculated for the uncatalysed reactions and for the reactions in which the extracts had been added. The final volumes of carbon dioxide evolved were also calculated. The arithmetic means of these volumes for each set̂ of determinations are given in Table I, and Table II shows the weight of tissue used and the final volume of each extract.

TABLE II

WEIGHTS OF CORNEAL TISSUE USED AND VOLUMES OF EXTRACT

\begin{tabular}{|c|c|c|c|c|c|}
\hline \multicolumn{4}{|c|}{ Extract } & Weight of Tissue (mg.) & Volume of Extract (ml.) \\
\hline $\begin{array}{cc}\text { Corneal A } & \ldots \\
\text { Corneal B } & \ldots \\
\text { Corneal C } & \ldots \\
\text { Corneal D } & \ldots \\
\text { Corneal E } & \ldots\end{array}$ & $\begin{array}{l}\cdots \\
\cdots \\
\cdots \\
\cdots\end{array}$ & $\begin{array}{l}\cdots \\
\cdots \\
\cdots \\
\cdots\end{array}$ & $\begin{array}{l}\ldots \\
\cdots \\
\cdots \\
\cdots \\
\cdots\end{array}$ & $\begin{array}{r}506 \\
1,638 \\
1,094 \\
413 \\
645\end{array}$ & $\begin{array}{r}12 \cdot 0 \\
37 \cdot 5 \\
22 \cdot 5 \\
9 \cdot 0 \\
9 \cdot 0\end{array}$ \\
\hline $\begin{array}{l}\text { Epithelial I } \\
\text { Endothelial I ... }\end{array}$ & $\ldots$ & $\ldots$ & $\ldots$ & $\begin{array}{r}40 \\
108\end{array}$ & $\begin{array}{l}3 \cdot 5 \\
3 \cdot 5\end{array}$ \\
\hline $\begin{array}{l}\text { Epithelial II ... } \\
\text { Endothelial II }\end{array}$ & $\begin{array}{l}\ldots \\
\ldots\end{array}$ & $\begin{array}{l}\ldots \\
\ldots\end{array}$ & $\begin{array}{l}\ldots \\
\ldots\end{array}$ & $\begin{array}{l}22 \\
23\end{array}$ & $\begin{array}{l}1 \cdot 5 \\
1 \cdot 5\end{array}$ \\
\hline $\begin{array}{l}\text { Epithelial III ... } \\
\text { Endothelial III }\end{array}$ & $\cdots$ & $\ldots$ & $\begin{array}{l}\ldots \\
\ldots\end{array}$ & $\begin{array}{l}53 \\
50\end{array}$ & $\begin{array}{l}3 \cdot 5 \\
3 \cdot 5\end{array}$ \\
\hline
\end{tabular}

The results given in Table I were submitted to statistical analysis, using Student's " $t$ "-test, and it was found that the volumes of carbon dioxide evolved after 60 and 120 seconds for the reactions in which the extracts were added did not differ significantly from those for the corresponding uncatalysed reactions. Moreover, there was no significant difference between the rates of the reactions in which fresh extract was added and those of the reactions in which the corresponding heated extract was used. The final volumes of carbon dioxide evolved were noi significantly different.

\section{Discussion}

The results obtained in these experiments show that carbonic anhydrase could not be demonstrated by the manometric procedure described in 
extracts prepared from the corneae of rabbits. Using the same method of carbonic anhydrase determination, a significant acceleration of the reaction can be obtained by the addition of a 1:10,000 dilution of rabbit's blood. It can therefore be calculated from these results that the concentration of carbonic anhydrase in the whole cornea cannot be greater than ${ }^{\frac{1}{0}} 0$ th of that in blood, while the concentrations of the enzyme in corneal epithelium and endothelium cannot be greater than $\Gamma_{10}^{1} 0$ th and $T_{10}^{\frac{1}{40}}$ th respectively of that in blood. The concentrations of the enzyme in the lens and in the ciliary body and iris of rabbits are approximately $\frac{1}{5}$ th and ${ }_{5}^{1} \frac{1}{0}$ th respectively of that in blood (Gloster and Perkins, 1955), so that it is evident that, if any carbonic anhydrase is present in the corneal tissues, its concencration is considerably less than in the other tissues in contact with the aqueous humour.

\section{Summary}

The carbonic anhydrase activicy of aqueous extracts of whole cornea, corneal epithelium, and corneal endothelium of rabbits was investigated by a manometric method. No evidence of carbonic anhydrase activity was found in the extracts.

\section{REFERENCES}

BAKKer, A. (1939). v. Graefes Arch. Ophthal., 140, 543. (1941). Ophthalmologica (Basel), 102, 351.

BECKER, B. (1954). Amer. J. Ophthal., 37, 13.

Gloster, J., and Perkins, E. S. (1955). J. Physiol. (Lond.), in the press.

KreBs, H. A., and Roughton, F. J. W. (1948). Biochem. J., 43, 550.

LANGHAM, M. E., and LeE, P. M. (1955). Trans. ophthal. Soc. U.K., 75, 229.

LEE, P. M. (1955). J. Physiol. (Lond.), 128, 80.

WISTRAND, P. J. (1951). Acta physiol. scand., 24, 144. 